\title{
SUGESTI TRADISIONAL BALI SEBAGAI LANDASAN PENDIDIKAN MORAL DAN ETIKA ANAK USIA DASAR
}

\author{
Anak Agung Gede Wiraputra; Ni Nyoman Nur Aditya Maha Yogi; \\ Kadek Aria Prima Dewi PF \\ Universitas Hindu Negeri I Gusti Bagus Sugriwa Denpasar \\ Agungwira9706@gmail.com; mahayogi97@gmail.com; \\ primadewipf@uhnsugriwa.ac.id
}

Diterima 5 April 2021, direvisi 10 April 2021, diterbitkan 1 Mei 2021

\begin{abstract}
Bali is an island that holds a myriad of local wisdom that amazes the world. One of the local wisdoms of Bali is traditional suggestion. Traditional Balinese suggestion is a half-oral folklore in the form of people's trust which is instilled early to the children as a foundation for good behavior in society. This paper seeks to explore traditional Balinese suggestions as the foundation of basic moral and ethical education for basic age children with a set of ethnographic and semiotic theories supported by content analysis and descriptive analysis methods. The results of this analysis show that there are some traditional suggestions that are familiar in Balinese life, namely: "Sing dadi negakin galeng, nyul busul jité" (may not sit on a pillow, then butt boils), "Sing dadi negakin lesung, nyanan jité amun lesungé gedénné" (may not sit on a place for pounding rice, the buttocks will be as big as a place for pounding rice), "Sing dadi ngutang nasi, nyanan matisiap selemé" (may not waste rice, the black chicken will die later), "Sing dadi ngetep kuku petengpeteng, nyanan énggal reramané mati" (may not cut nails at night, his parents may die soon), "Sing dadi negakin talenan, nyanan kebus jité" (may not sit on the cutting board, because it can cause the butt to become hot), "Sing dadi nyampat petengpeteng, nyanan ada anak nugtug" (may not sweep at night, there will be someone to follow), and "Sing dadi mambuh nuju kajeng kliwon, nyanan kadena bisa ngleak" (may not wash head when Kajeng Kliwon day, later thought to have black magic I magic / can be tricky). This traditional suggestion has an important role as the foundation of ethics and morality education in basic age children, such as: forming children into polite personalities, forming attitudes of compassion and social care, fostering an attitude of respecting God's grace in the form of food, and fostering a loving attitude towards oneself and people other.
\end{abstract}

Keywords: Local Wisdom, Traditional Suggestions, Ethical and Moral Education.

\footnotetext{
Abstrak

Bali merupakan pulau yang menyimpan segudang kearifan lokal yang mempu memukau dunia. Salah satu kearifan lokal Bali adalah sugesti tradisional. Sugesti tradisional Bali merupakan folklore setengah lisan berupa kepercayaan rakyat yang ditanamkan sejak dini kepada anak-anak sebagai landasan bertingkah laku yang 


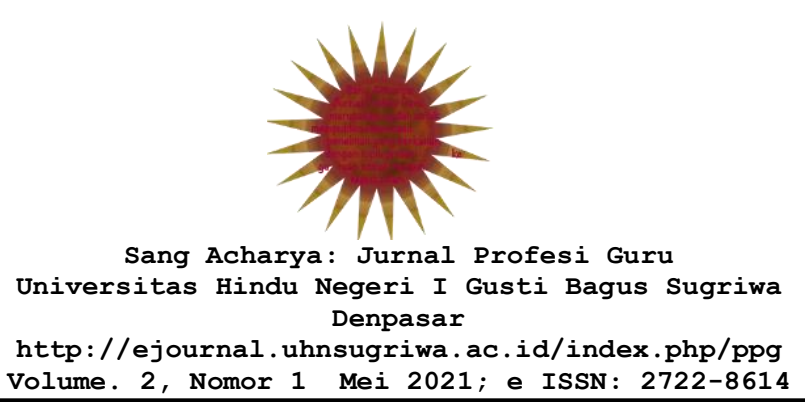

baik di masyarakat. Tulisan ini berusaha untuk mengupas sugesti tradisional Bali sebagai landasan pendidikan moral dan etika anak usia dasardengan perangkat teori etnografi dan semiotik yang didukung oleh metode analisisisi dan deskriptif analisis. Hasil dari analisis tersebut menunjukkan bahwa terdapatbeberapa sugesti tradisional yang familiar dalam kehidupan masyarakat Bali, yaitu: "Sing dadi negakin galeng, nyanan busul jité" (tidak boleh menduduki bantal, nanti pantatnya bisul), "Sing dadi negakin lesung, nyanan jité amun lesungé gedénné" (tidak boleh menduduki tempat menumbuk padi, nantipantatnya sebesar tempat menumbuk padi), "Sing dadi ngutang nasi, nyanan mati siap selemé" (tidak boleh membuangbuang nasi, nanti ayam hitamnya mati), "Sing dadi ngetep kuku peteng-peteng, nyanan énggal reramané mati" (tidak boleh potong kuku di malam hari, nanti orang tuanya bisa cepat meninggal), "Singdadi negakin talenan, nyanan kebus jité" (tidak boleh menduduki talenan, karena dapat menyebabkan pantat menjadi panas), "Sing dadi nyampat peteng-peteng, nyanan ada anak nugtug" (tidak boleh menyapu di malam hari, nanti ada yang membuntuti), dan "Sing dadi mambuh nuju kajeng kliwon, nyanan kadena bisa ngleak" (tidak boleh keramas saat hari kajeng kliwon, nanti dikira memiliki ilmu hitam/magic/bisa ngléak). Sugesti tradisional tersebut memiliki peranan penting sebagai landasan pendidikan etika dan moralitas pada anak usia dasar, yaitu: membentuk anak menjadi pribadi yang sopan, membentuk sikap tenggang rasadan peduli sosial, menumbuhkan sikap menghargai anugerah Tuhan berupa makanan, dan menumbuhkan sikap menyayangi diri sendiri dan orang lain.

Kata Kunci: Kearifan Lokal, Sugesti Tradisional, Pendidikan Etika dan Moral.

\section{PENDAHULUAN}

Bali merupakan tempat dengan segudang kearifan lokal yang mendunia. Masyarakat dunia berbondong-bondong datang ke Bali hanya untukmenyaksikan keunikan kearifan lokal di Bali, baik yang dipentaskan dalam upacara, dilaksanakan dalam keseharian, maupun dipentaskan secara profan sebagai pertunjukan untuk wisatawan. Tidak hanya wisatawan yang sebatasingin berlibur ke Bali, kearifan lokal Bali juga menjadi daya tarik yang luar biasa bagi para peneliti dari dalam negeri maupun luar negeri, karena kekayaan tradisi, adat, serta unsur tradisional dalam kebudayaan Bali menjadi ladang penelitian etnografi yang sangat strategis. Kearifan lokal di Bali apabila dikalkulasikan memiliki jumlah yang sangat banyak, karena selain yang telah terkenal dan diketahui oleh kalangan secara luas, masih banyak sekali manik- manik kearifan lokal yang terpendam dan belum digali. Kearifan lokal tersebut tentunya mengandung berbagai pesan kebijaksanaan dan nilai yang berguna bagi kehidupan (Alit, 2009: v). Dari berbagai jenis kearifan lokal Bali, sugesti tradisional adalah salah satu wujud kearifan lokal Bali yang rutin diajarkan serta ditanamkan turun-temurun secara lisan oleh tetua atau orang tua di Bali kepada generasi penerusnya sebagai wujud usaha penanaman nilai-nilai etika serta moralitas sederhana yang mudah dicerna oleh pemikiran anak usia dasar. Dari segi bentuknya, sugesti tradisional termasuk dalam wilayah folklore, khususnya folklore setengah lisan yang disebut dengan kepercayaan rakyat. Adapun ciri-ciri sugesti tradisional sebagai bagian dari 


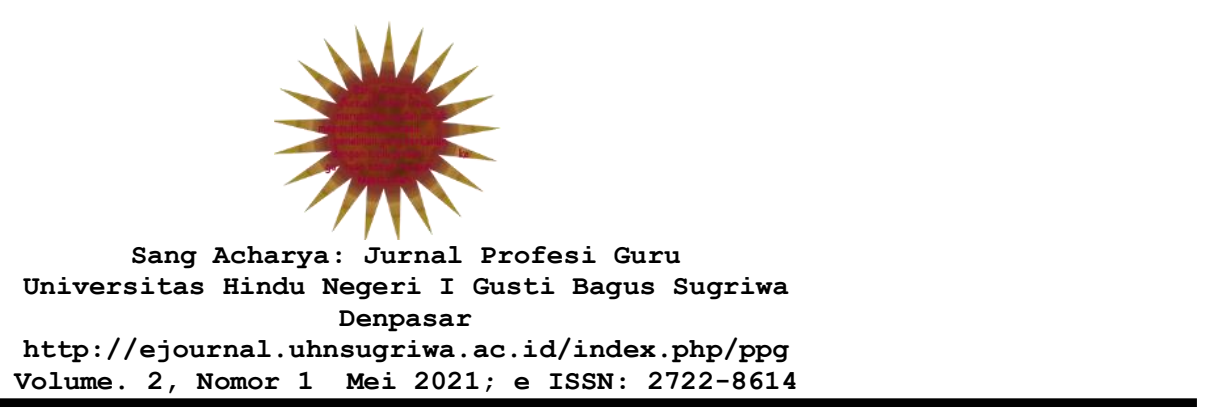

folklore adalah tidak diketahui pencetusnya (anonim), bersifat tradisional, diwariskan secara turun-temurun,

serta disebarkan dari mulut ke mulut (secara verbal), dan menjadi milik bersama (Danandjaja, 1997: 3-4).

Sugesti tradisional mengambil bahan dari berbagai benda maupun unsur alam yang dekat dengan manusia, sehingga akan lebih cepat dipahami oleh pemikiran anak usia dasar. Apabila dipikir secara logika, terkadang sugesti tradisional sama sekali tidaklah masuk akal, namun apabila dilihat dari dampaknya secara mental, konsistennya penanaman sugesti tradisional kepada anak usia dini akan menyebabkan sang anak memiliki etika dan moralitas yang baik saat dewasa. Salah satu contoh sugesti tradisional Bali adalah: "Sing dadi negakin galeng, nyanan busul jité" (tidak boleh menduduki bantal, nanti pantatnya bisul). Apabila ditelaah secara ilmu pengetahuan, menduduki bantal tidaklah berpengaruh pada kebisulan, karena bisul adalah penyakit kulit yang disebabkan oleh bakteri yang bernama staphylococcus aureus yang didukung oleh adanya infeksi, kontak dengan penderita, maupun pola hidup yang buruk (Jawetz dan Adelberg, 2008). Apabila anak kecil ditakut-takuti oleh istilah bisul yang dianggap sebagai sesuatu yang menyakitkan, maka mereka akan secara otomatis tidak berani menduduki bantal, karena sangat takut akan penyakit bisul.Di balik sugesti tersebut sebenarnya tertanam suatu nilai moral dan etika yang sarat dengan ajaran budi pekerti. Bantal dalam kehidupan masyarakat Bali diyakini sebagai benda yang digunakan sebagai penyangga kepala pada saat tidur. Dalam kepercayaan Bali, kepala adalah anggota badan yang dianggap sakral, sehingga posisinya adalah di hulu (luanan). Sedangkan pantat adalah unsur tubuh manusia yang dianggap bersifat profan, sehingga tempatnya di hilir (tebén). Oleh karena itu, sangatlah tidak sopan apabila seorang anak menduduki bantal, karena sudah melanggar aturan etika dalam berprilaku. Namun, dalam hal ini, agar pembelajaran etika tersebut lebih mudah dicerna oleh anak usia pendidikan dasar, maka digunakanlah kalimat hukuman yang dapat menakut- nakuti anak tersebut, yaitu dengan membangun sugesti bahwa apabila sang anak menduduki bantal, maka ia akan terkena penyakit bisul.

Berdasarkan uraian latar belakang di atas, penulis merasa tergugah untuk mengangkat sugesti tradisional tersebut melalui karya ilmiah berupa artikel jurnal ilmiah. Tulisan ini merupakan bentuk pertanggungjawaban secara ilmiah agar isi dari karya ini dapat dibaca dan dipertimbangkan oleh khalayak luas dan akhirnya dilaksanakan sebagai salah satu cara terbaik untuk menanamkan etika dan moralitas pada anak usia dasar. Hal tersebut sangat penting, karena pendidikan dasar adalah salah satu penentu penting dalam pembentukan karakter anak, sehingga apabila seorang anak mendapatkan pendidikan dasar berupa etikadan moralitas yang baik, maka karakter anak saat dewasa akan cenderung ke karakter yang positif. Adapun batasan pembahasan dari karya ini adalah pada pengenalan macam-macam sugesti tradisional Bali serta peranannya sebagai landasan pendidikan etika dan moralitas pada anak usia dini. Pisau pembedah dari karya ilmiah yang berbentuk penelitian kualitatif ini adalah teori etnografi dan semiotik. 


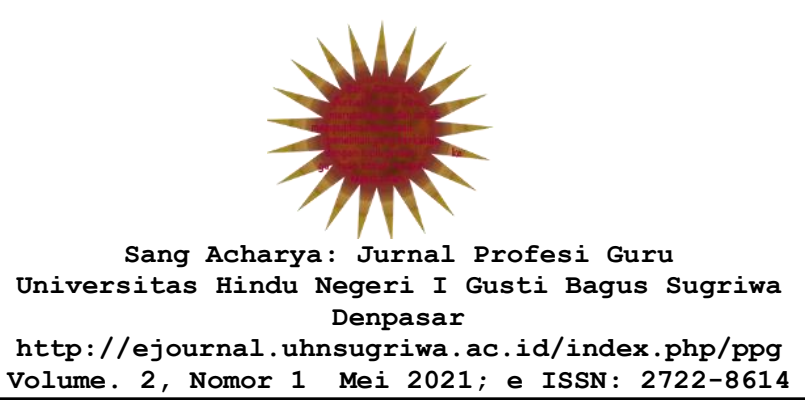

Data penelitian ini diperoleh dari hasil observasi, wawancara, sertastudi pustaka yang dikelola dalam teknik analisis data berupa reduksi data,display data, serta penarikan kesimpulan.

\section{PEMBAHASAN}

\subsection{Macam-Macam Sugesti Tradisional Bali}

Sugesti tradisional Bali merupakan salah satu sarana mendidik anak usia dini yang telah ditanamkan oleh leluhur orang Bali dari dahulu hingga sekarang. Cara pewarisannya pun dilakukan dari mulut ke mulut dan tidak diketahui siapa pencipta ataupun pencetusnya. Sugesti tradisional Bali memiliki bentuk berupa wacana sederhana yang terdiri dari dua kalimat yang menunjukkan pola sebab dan akibat. Secara logika, pola sebab dan akibat dalam sugesti tradisional Bali tersebut sebagian besar tidaklah masuk akal (terdapat sebagian kecil sugesti tradisional Bali yang masuk akal), namun di balik itu terdapat makna serta terjemahan maksud yang mendalam, baik secara makna empiris maupun mengarah ke ajaran etika dan moralitas. Apabila didata dengan seksama, Bali menyimpan berbagai macam sugesti tradisional, namun karena keterbatasan ruang dan waktu, dalam tulisan ini hanya akan diuraikan beberapa sugesti tradisional Bali yang universal dan dikenal secara luas oleh masyarakat Bali.

\subsubsection{Sing Dadi Negakin Lesung, Nyanan Jité Amun Lesungé Gedénné}

Sugesti tradisional Bali yang berbunyi "Sing dadi negakin lesung, nyanan jité amun lesungé gedénné" berarti "Tidak boleh menduduki tempat menumbuk padi, nanti pantatnya sebesar tempat menumbuk padi". Lesung merupakan alat penumbuk butir padi tradisional yang digunakan oleh orang Bali di zaman dahulu untuk memisahkan antara beras dan kulitnya. Biasanya lesung ditumbuk oleh beberapa wanita secara bersama-sama dan menggunakan tempo tumbukan yang selang seling, sehingga menimbulkan alunan suara ritmis yang enak didengar. Dalam kepercayaan masyarakat Jawa maupun Bali, lesung adalahsalah satu sarana tradisional yang disucikan, karena menjadi simbol dari dewiSri (Dewi Kesuburan) dan dipercaya sebagai alat yang sangat penting untuk kesejahteraan masyarakat (Astono, 2002: 1). Sebelum teknologi berupa mesin penggiling padi ditemukan, lesung menjadi alat utama untuk memisahkan padi dan kulitnya. Oleh karena itu, sampai saat ini pun lesung merupakan benda yang memiliki nilai sakral, selalu dihaturkan sesajen, dan tidak boleh diletakkan sembarangan. Bahkan ditengkurapkan pun tidak boleh, karena lesung harus diletakkan dengan posisi yang tegak dan lubangnya menghadap ke atas. Masyarakat Bali mempercayai bahwa apabila lesung ditengkurapkan atau lubangnya menghadap ke bawah, maka rejeki keluarga tersebut akan tersendat atau tertutup.

Berkaitan dengan uraian di atas, sudah sangatlah jelas bahwa lesung menjadi alat tradisional yang sangat dihormati oleh masyarakat Bali. Oleh karena itu, timbullah sugesti tradisional yang mengatakan bahwa tidak boleh menduduki lesung atau tempat menumbuk beras, karena tempat tersebut sangat disucikan dan menjadi lambang kesuburan (Dewi Sri). Anak-anak yang memiliki rasa ingin tau yang besar tentunya pernah secara sengaja atau tidak sengaja menduduki lesung karena mereka tidak tahu. Saat itulah sugesti tradisional ditanamkan oleh orang 


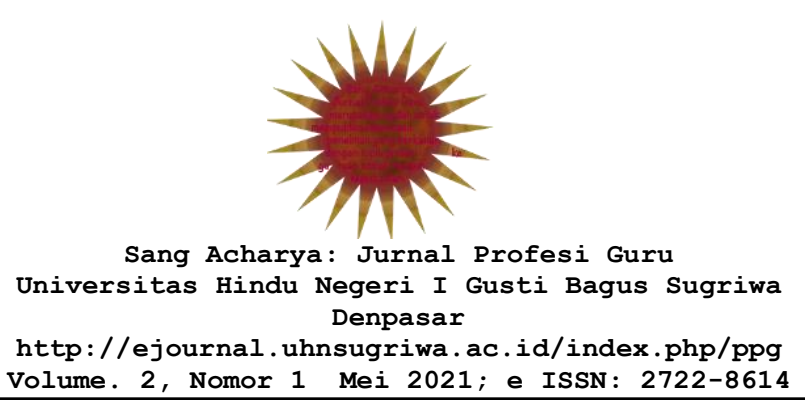

tua dengan mangatakan bahwa apabila menduduki lesung, maka pantat mereka akan menjadi sebesar lesung. Tentunya anak kecil akan sangat takut mendengar perkataan tersebut, sehingga segera beranjak dari lesung yang telah mereka duduki dan tidak akan pernah

menduduki lesung lagi. Secara logika, lesung hanyalah tempat menumbuk padi yang terbuat dari batu atau kayu, sehingga sangat tidak mungkin menyebabkan pantat menjadi bengkak. Tetapi, disanalah kekuatan sugesti memainkan perannya. Maksud dari itu semua adalah agar anak-anak tidak menduduki lesung yang notabena adalah benda yang dihormati, disucikan, dan selalu dihaturkan sesajen oleh masyarakat Bali. Pantat dianggap sebagai bagian tubuh yang profan (tebén), sehingga tidaklah pantas menduduki lesung yang dihormati dan disucikan oleh masyarakat Bali.

\subsubsection{Sing Dadi Ngutang Nasi, Nyanan Mati Siap Selemé}

Sugesti tradisional yang berbunyi "Sing dadi ngutang nasi, nyanan mati siap selemé" berarti tidak boleh membuang-buang nasi, nanti ayam hitamnya mati. Ayam hitam dijadikan objek dalam sugesti tradisional ini, karena warna hitam merupakan simbol dari Dewa Wisnu sebagai pemelihara yang identik dengan air/kesuburan maupun kesejahteraan. Warna hitam juga dapat diartikan sebagai kasih sayang, kelembutan, dan ketenangan (Asthararianty, dkk, 2016: 34). Di sisi lain, nasi adalah makanan pokok yang berasal dari padi, dimana padi merupakan perlambang dari Dewi Sri sebagai Dewi kesuburan/kesejahteraan. Oleh karena itu, membuang-buang nasi sama juga halnya dengan membuang rejeki atau menjauhkan manusia dari kesejahteraan. Apabila dinalar secara logika pendek, membuang-buang nasi tidaklah ada hubungannya dengan matinya ayam hitam, apalagi anak kecil yang membuang nasi (entah karena tidak mampu menghabiskan atau karena tidak nafsu makan) kebetulan tidak mempunyai ayam hitam di rumahnya. Ayam hitam dijadikan objek karena ayam hitam adalah tokoh yang lekat di hati anak-anak, apalagi yang sudah pernah mendengar dongeng "I Siap Selem", sehingga sangat familiar di telinga anak- anak. Apalagi kebetulan di rumah si anak terdapat ayam hitam, maka orang tua akan lebih mudah untuk menganalogikan peringatan kepada anak bahwa ayam hitam di rumahnya itu akan mati akibat ulah si anak yang membuang-buang nasi. Dengan ditakut-takuti seperti itu, maka efektif sekali anak tersebut tidak akan membuang-buang nasinya. Selain untuk dirinya sendiri, sang anak juga akan menyampaikan sugesti tersebut kepada teman-temannya apabila ia melihat ada temannya yang membuang-buang nasi.

\subsubsection{Sing Dadi Ngetep Kuku Peteng-Peteng, Nyanan Énggal Reramané Mati}

Sugesti tradisional yang menyatakan "Sing dadi ngetep kuku peteng- peteng, nyanan enggal reramané mati" berarti tidak boleh potong kuku di malam hari, nanti orang tuanya bisa cepat meninggal. Sugesti tradisional ini apabila dipertimbangkan dari segi logika atau akal sehat, memang korelasinya sangatlah jauh antara memotong kuku dan kematian orang tua. Namun, apabila dilihat dari kepercayaan Bali, kuku adalah benda yang sangat riskan apabila dibuang 


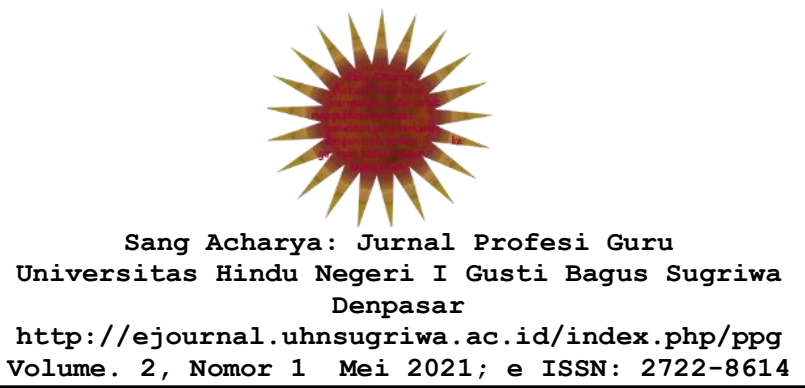

sembarangan, apalagi di malam hari. Diyakini bahwa orang yang memiliki ilmu hitam (bisa ngléak) sangatlah mudah menemukan potongan kuku seseorang apabila dibuang pada malam hari. Selain itu, kuku juga merupakan media yang sangat ampuh untuk menyakiti orang lain secara ilmu hitam. Tidak hanya menyakiti yang mempunyai potongan kuku tersebut, tetapi juga keluarganya, termasuk yang paling riskan adalah orang tuanya (hasil wawancara

dengan Anak Agung Gede Raka Sukawati pada Senin, 11 Mei 2020). Oleh karena itu, masyarakat Bali sangatlah melarang untuk memotong kuku di malam hari, sehingga kepercayaan itu juga ditanamkan kepada anak-anak agar mereka tidak memotong kuku di malam hari. Di sisi lain, apabila dialihkan kepada pemikiran di luar kepercayaan masyarakat, memotong kuku di malam hari memanglah sangat berbahaya, apalagi dilakukan oleh anak kecil. Hal tersebut dikarenakan pada malam hari, ketajaman indra penglihatan menjadi berkurang, meskipun sudah ada di bawah sinar lampu. Keadaan tersebut sangat memungkinkan kutikula kuku terpotong akibat anak kecil kurang terampil memotong kuku dan penglihatan mereka terbatas akibat memotong kuku dimalam hari. Kutkula kuku yang terpotong bisa membahayakan kesehatan, sehingga tidak disarankan untuk memotong kuku di malam hari.

\subsubsection{Sing Dadi Negakin Talenan, Nyanan Kebus Jité}

Sugesti tradisional yang berbunyi "Sing dadi negakin talenan, nyanankebus jité" berarti tidak boleh menduduki talenan, karena dapat menyebabkan pantat menjadi panas. Sebelum membahas lebih jauh, dalam hal ini talenan yang dimaksud adalah talenan tradisional masyarakat Bali yang biasanya berbahan dari batang kayu Celagi (Pohon Asam). Sugesti tradisional ini apabila dianalisis secara logika cukup masuk akal, karena masyarakat Bali sangat aktif menggunakan rempah-rempah untuk bumbu masakan, mulai dari lengkuas, kunyit, bawang merah, bawang putih, merica, termasuk cabe yang disebut basa genep. Oleh karena itu, pasti sisa-sisa dari bumbu tersebut masih menempel di talenan, sekalipun telah dicuci. Hal tersebutlah yang sangat memungkinkan anakkecil yang menduduki talenan akan merasakan sensasi panas terbakar di bagian pantatnya akibat dari sisa-sisa basa genep yang mengendap di permukaan talenan. Selain itu, sensasi panas yang disebabkan oleh talenan bekas membuat basa rajang/basa genep (bumbu Bali lengkap) bisa dirasakan berhari-hari, sehingga anak kecil akan sangat tersiksa. Oleh karena itu, sugesti tradisional tersebut membuat anak kecil menjadi takut untuk menduduki talenan. Di sisi lain, apabila dikaitakan dengan kepercayaan masyarakat Bali, talenan merupakan tempat bersthananya Sang Hyang Siwa Bhairawi (Siwa Bhairawa), karena talenan merupakan tempat penjagalan maupun eksekusi bebagai bahan makanan, baik itu dari hewan maupun tumbuhan sebelum menjadi olahan makanan. Hal tersebut menandakan bahwa talenan disamakan dengan pamuhunan dan balé pabasmian (tempat pembakaran mayat dalam upacara ngaben) karena sama-sama menjadi tempat bersthananya Sang Hyang Siwa Bhairawi (Hasil wawancara dengan Ida Bagus Putra Pudharta pada Senin, 11 Mei 2020). Atas dasar tersebut, talenan menjadi sarana yang selalu dihaturkan sesajen oleh mayarakat Hindu Bali, sehingga sangatlah tidak boleh 


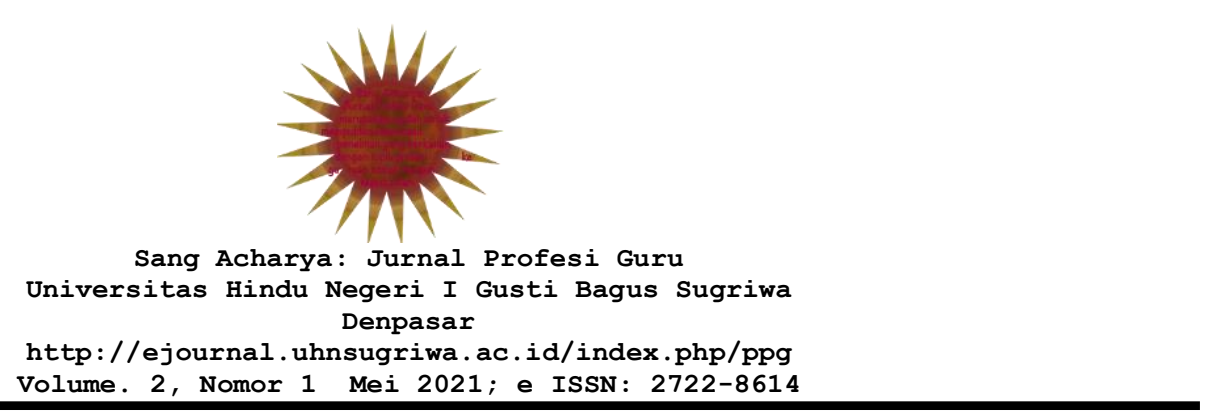

digunakan secara sembarangan, apalagi sampai diduduki.

\subsubsection{Sing Dadi Nyampat Peteng-Peteng, Nyanan Ada Anak Nugtug}

Sugesti tradisional Bali yang berbunyi "Sing dadi nyampat peteng-peteng, nyanan ada anak nugtug" berarti tidak boleh menyapu di malam hari, nanti ada yang membuntuti. Membuntuti dalam hal ini adalah akan ada mahluk halus yang mengikuti seseorang yang menyapu di malam hari. Dalam kepercayaan

masyarakat Bali, sangat tidaklah diperbolehkan untuk menyapu di malam hari, karena dapat mengundang mahluk halus untuk mendekati seseorang yang menyapu tersebut. Hal itu dikarenakan suara sapu lidi di malam hari merupakan sarana yang dapat memecah kesunyain malam serta mengundang berbagai mahluk halus yang ada di sekitar tempat tersebut untuk menuju ke sumber suara (hasil wawancara dengan Anak Agung Gede Raka Sukawati pada Senin, 11 Mei 2020). Di sisi lain, dari segi logika, menyapu di malam hari dapat mendatangkanbanyak kerugian. Salah satu kerugiannya adalah barang-barang yang disaputidak terlalu jelas kelihatan, sehingga sangat beresiko benda-benda yang penting ikut tersapu, seperti uang, pisau, cincin, dan benda lain yang tidak sengajatersapu karena tidak terlalu jelas kelihatan. Selain hal tersebut, menyapu dimalam hari juga dapat mengganggu ketenangan orang lain akibat suaranya yang lumayan keras, sehingga dapat mengganggu waktu istirahat orang lain. Oleh karena itu, anak-anak di Bali selalu disugesti bahwa kalau menyapu di malam hari, maka akan dibuntuti oleh mahluk halus, agar anak tersebut segera menghentikan aktivitasnya menyapu atau bermain dengan sapu dan segera masuk ke dalam rumah untuk beristirahat.

\subsubsection{Sing Dadi Mambuh Nuju Kajeng Kliwon, Nyanan Kadena Bisa Ngléak}

Sugesti tradisional Bali yang berbunyi "Sing dadi mambuh nuju kajeng kliwon, nyanan kadena bisa ngleak" memiliki arti jangan keramas saat hari kajeng kliwon, nanti dikira menguasai ilmu hitam (magic/ngléak). Dalam kepercayaan masyarakat Bali, kajeng kliwon merupakan hari yang sangat keramat, karena dipercayai bahwa saat itu merupakan waktu beryoganya Dewa Siwa dengan segala kekuatannya, sehingga pada saat itu dipercaya sebagai waktu bangkitnya berbagai macam kekuatan (bebhutan) maupun bermacam-macam wujud ilmu hitam. Hari yang lebih riskan dari kajeng kliwon adalah pamagpag kajeng kliwon (satu hari sebelum kajeng kliwon). Di hari pamagpag kajeng kliwon, orang-orang yang menguasai ilmu hitam diyakini berkeliaran untuk mencari berbagai macam makanan yang tentunya bukanlah makanan biasa, namun hal-hal menjijikkan seperti ngisep bebangkan (menghisap sari dari bagian mayat manusia) yang terdapat di kuburan, maupun berbagai hal menjijikkan lainnya yang dilihat sebagai makanan sedap oleh yang memiliki ilmu tersebut. Hal itulah yang menyebabkan pada saat kajeng kliwon, orang- orang yang memiliki ilmu hitam tersebut membersihkan diri dengan cara mandi dan keramas karena kemarin malamnya mereka habis memakan dan menghisap hal-hal menjiikkan di kuburan. Maksud dari pembersihan tersebut adalah agar pada saat kajeng kliwon mereka dapat memuja Dewa Siwa yang pada saat itu sedang beryoga. Dengan adanya pemujaan tersebut, maka mereka menujukkan bhakti terhadap sumber dari segala 


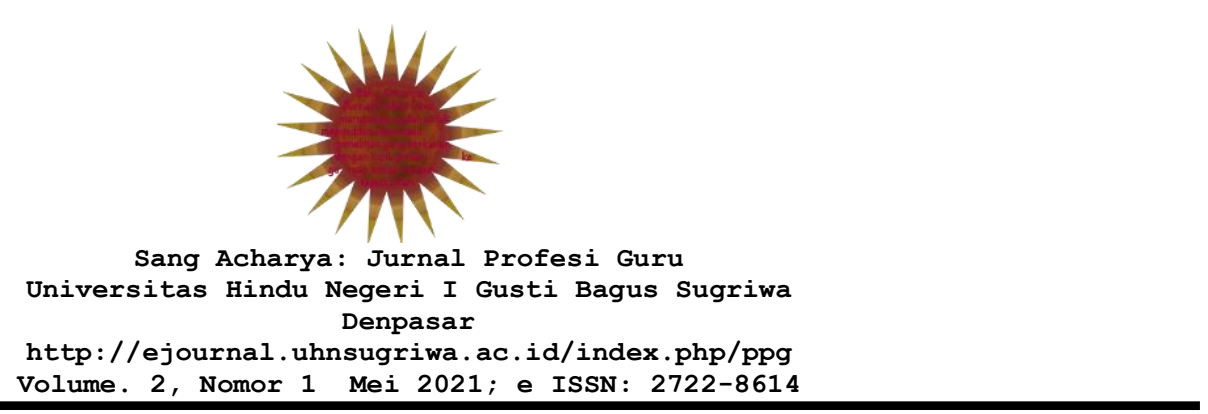

sumber kekuatan, termasuk ilmu hitam yang bagi umat awam terlihat sangat mengerikan (hasil wawancara dengan Anak Agung Gede Raka Sukawati pada Senin, 11 Mei 2020). Dengan adanya kepercayaan tersebut sudah tentu para orang tua selalu mengingatkan kepada anak-anak mereka agar jangan sampai keramas pada saat kajeng kliwon sebagai bentuk antisipasi agar tidak terpengaruh oleh kekuatan-kekuatan negatif dengan cara menakut-nakuti anak-anak tersebut dengan sosok manutkan seperti léak.

\subsection{Peranan Sugesti Tradisional Bali sebagai Landasan Pendidikan Moral Dan Etika Anak Usia Dasar}

Sugesti tradisional Bali seperti telah disebutkan pada uraian di atas adalah salah satu kearifan lokal masyarakat Bali yang sangat ampuh untuk menjadi sarana kontrol sosial maupun langkah awal pengenalan tata berperilaku kepada anak agar nantinya terbentuk karakter yang baik dan diterima dalam lingkungan masyarakat. Moral dan etika menjadi hal yang sangat penting untuk diperhatikankarena dengan adanya dasar pendidikan moralitas dan etika yang baik, maka nantinya karakter yang tumbuh dalam diri anak akan cenderung menuju ke arah karakter positif. Sugesti tradisional juga memiliki kelebihan, yaitu sang anak menjadi takut untuk melanggar karena telah terpampang jelas sanksi yang akan didapatkan apabila melanggar, apalagi sanksi tersebut berbau hal-hal yang mistis, sehingga sang anak akan berusaha untuk tidak melanggar ketentuan- ketentuan yang telah diatur dalam sugesti tradisional tersebut. Sugesti tradisionaljuga sangat mudah dicerna oleh anak, karena dikemas dengan bahasa yang mudah dimengerti dan tidak bertele-tele, meskipun sebenarnya di balik itu semua terdapat makna mendalam yang nantinya secara pelan namun pasti akan dimengerti oleh sang anak setelah ia bertumbuh dewasa. Dengan adanya kelebihan tersebut, maka sugesti tradisional hingga sekarang menjadi kearifan lokal yang masih relevan untuk memegang peranan penting sebagai landasan pendidikan etika dan moralitas pada anak usia dini. Adapun peranan tersebut secara lebih detail diuraikan pada penjelasan di bawah ini.

\subsubsection{Membentuk Anak menjadi Pribadi yang Sopan}

Sugesti tradisional Bali memiliki peran yang sangat penting dalam membentuk anak menjadi pribadi yang memiliki sopan santun. Hal tersebut dikarenakan ketentuan yang terdapat dalam sugesti tradisional tersebut tiada lain berpatokan kepada nilai-nilai etika dan sopan santun agar seorang anak diterima dalam masyarakat tempatnya tinggal. Sebagai contohnya adalah sugesti tradisional yang berbunyi: "Sing dadi negakin galeng, nyanan jité busul" (tidak boleh menduduki bantal, nanti pantatnya bisul), "Sing dadi negakin lesung,nyanan jité amun lesungé gedenné" (tidak boleh menduduki lesung, nanti pantatnya menjadi sebesar lesung), dan "Sing dadi negakin talenan, nyanan kebus jité" (tidak boleh menduduki talenan, nanti pantatnya panas). Ketiga sugesti tradisioanl tersebut bertujuan untuk membentuk pribadi anak menjadi insan yang sopan dan tau tata krama.

Bantal adalah alat untuk menyangga kepala pada saat tidur, sehingga 


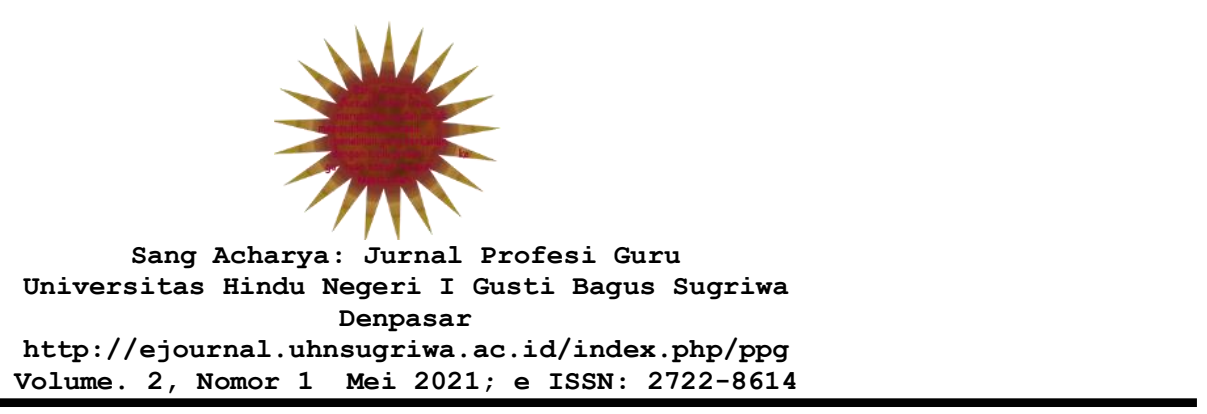

sangatlah tidak sopan apabila seseorang menduduki bantal. Meskipun dalam kasus lain memang ada bantal yang dibuat untuk diduduki. Namun pada prinsipnya bantal adalah sanggaan kepala yang tidak boleh diduduki. Hal tersebut juga berlaku pada lesung. Lesung tiada bedanya dengan benda yang mampu membuat masyarakat Bali bisa bertahan hidup di zaman dahulu, karena hanya lesung yang menjadi alat untuk memisahkan butir padi dengan kulitnya, sehingga bisa dikonsumsi oleh masyarakat Bali. Lesung memiliki peranan besar dalam perjalanan kehidupan masyarakat bali, sehingga tidaklah berlebihan apabila lesung sangat dihormati dan selalu dihaturkan sesajen hingga saat ini. Tentunya seorang anak akan terlihat sangat tidak sopan apabila berani

menduduki lesung, apalagi sampai menginjak dan berdiri di atas lesung. Perbuatan seperti itu tidaklah terpuji. Yang ketiga adalah talenan. Talenan menjadi alat yang sangat diperlukan dan penting untuk kegiatan memasak. Tidak hanya itu, dalam masyarakat Bali, talenan juga menjadi tempat bersthananya Sang Hyang Siwa Bhairawi. Oleh karena itu, sangatlah tidak terpuji apabila seorang anak dengan seenaknya menduduki talenan. Dengan adanya larangan untuk menduduki ketiga benda tersebut dengan sanksi yang disebutkan oleh sugesti tradisional, maka secara otomatis sang anak akan merasa takut untuk melanggar karena takut dengan sanskinya. Dengan adanya ketakutan tersebut, maka sang anak akan senantiasa berperilaku sopan dengan tidak menduduki bantal, lesung, maupun talenan saat berada di rumahnya sendiri maupun ditempat lain.

\subsubsection{Membentuk Sikap Tenggang Rasa dan Peduli Sosial}

Dalam kehidupan dewasa ini sangatlah banyak orang yang tidak memiliki sikap tenggang rasa dan peduli sosial. Orang-orang seperti itu hanya memikirkan kebaikan untuk dirinya sendiri tanpa peduli dengan orang di sekitarnya. Apalagi zaman globalisasi saat ini membuat orang-orang semakin liberal dan mementingkan diri sendiri. Orang-orang yang demikian kurang memiliki dasar sikap tenggang rasa dan peduli sosial yang kuat, sehingga mudah tergerus dengan pengaruh zaman. Untuk menyikapi hal tersebut, sugesti tradisional dari sejak dini menjadi hal yang tidak hanya perlu, namun dibutuhkan untuk menciptakan generasi yang memiliki dasar peka sosial dan tenggang rasa yang tinggi pada anak. Oleh karena itu, penanaman sugesti tradisional memiliki dampak yang sangat besar untuk kehidupan seorang anak saat dewasa, terutama dalam hal membentuk karakter anak yang peduli sosial dan tenggang rasa.

Adapun sugesti tradisional seperti "Sing dadi nyampat peteng-peteng, nyanan ada anak nugtug" (tidak boleh menyapu di malam hari, nanti ada yang membuntuti) adalah salah satu sugesti tradisional yang mengajarkan anak untuk memiliki sikap tenggang rasa dan peduli sosial. Malam hari merupakan saat orang-orang beristirahat atau menghabiskan waktu berkualitas bersama keluarga dalam suasana damai. Apabila seorang anak dengan semangatnya menyapu dengan sapu lidi di malam hari, maka secara otomatis akan menimbulkan suara berisik yang dapat mengganggu ketenangan serta dapat membuat orang-orang ataupun tetangga menjadi terganggu. Suara dari sapu lidi di malam hari juga terdengar sangat aneh dan menakutkan apabila didengar dari kejauhan, sehingga 


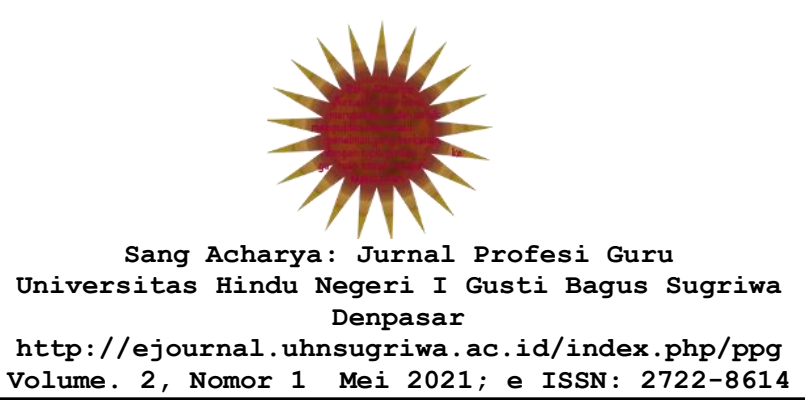

akan menyebabkan orang lain menjadi takut dan resah. Oleh karena itu, sugesti tradisional Bali yang tidak mengizinkan anak untuk menyapu di malam hari atau bermain dengan sapu lidi di malam hari juga memiliki dampak besar untuk menumbuhkan sikap tenggang rasa dan peduli dengan keadaan sosial, sehingga sang anak nantinya tidak akan tumbuh menjadi pribadi yang mementingkan diri sendiri.

\subsubsection{Menumbuhkan Sikap Menghargai Anugerah Tuhan berupa Makanan}

Makanan adalah kebutuhan pokok yang harus dipenuhi oleh semua manusia agar dapat bertahan hidup. Oleh karena itu, semua orang bekerja banting tulang demi mendapatkan penghasilan yang salah satunya digunakan

untuk melengkapi kebutuhan pangan keluarga. Dengan berharganya makanan tersebut, tentunya sangatlah mubazir dan sangat tidak baik apabila makanan dibuang-buang percuma. Salah satu sugesti tradisional Bali yang berbunyi "Sing dadi ngutang nasi, nyanan mati siap selemé" (tidak boleh membuang-buang nasi, nanti ayam hitamnya mati) mengajarkan sikap yang sangat mulia terhadap anak, yaitu tidak boleh membuang-buang makanan, karena makanan adalah wujud anugerah Tuhan yang harus dihargai dan dimanfaatkan dengan sebaik mungkin. Makanan dibeli dengan uang dan uang dicari dengan kerja keras oleh orang tua sang anak, sehingga sebagai anak yang baik haruslah menghargai makanan sebagai wujud menghargai anugerah Tuhan dan menghargai usaha keras orang tua untuk menghidupi keluarga. Sugesti tradisional Bali tersebut menggunakan objek siap selem agar sang anak merasa bersalah karena telah membunuh hewan sekaligus karakter yang dikenal dalam satua I Siap Selem hanya karena ia membuang nasinya. Oleh karena itu, pada saat makan di manapun dan kapanpun sang anak tidak akan membuang-buang nasinya dan akan mengingatkan temantemannya apabila ada yang membuang-buang nasi.

\subsubsection{Menumbuhkan Sikap Menyayangi Diri Sendiri dan Orang Lain}

Sikap menyayangi diri sendiri maupun mencintai sesama adalah sikap yang harus ditumbuhkan dalam diri anak sejak dini. Dengan adanya sikap cinta terhadap diri sendiri, keluarga, maupun sesama manusia, maka seorang anak akan tumbuh menjadi pribadi yang bersahaja, simpati, dan selalu ringan tangan dalam membantu sesama. Sugesti tradisional Bali yang berbunyi "Sing dadi mambuh nuju kajeng kliwon, nyanan kadena bisa ngleak" (jangan keramas saat hari kajeng kliwon, nanti dikira bisa ilmu hitam/magic/ngléak) dan "Sing dadi ngetep kuku peteng-peteng, nyanan énggal reramané mati" (tidak boleh potong kuku di malam hari, nanti orang tuanya bisa cepat meninggal) mengajarkan anakagar senantiasa menyayangi diri sendiri dan keluarganya, khususnya orang tuanya. Sugesti tradisional Bali yang melarang keramas saat kajeng kliwon,terutama untuk anak perempuan memiliki peranan yang besar dalam hal menyayangi diri sendiri, karena seorang anak akan membawa kebiasaan tersebut sampai dewasa dan mencegah dirinya dari omongan orang-orang yang menuduh bahwa ia bisa ngléak saat telah menikah. Dengan hal tersebut, maka secara tidak langsung si anak telah mempersiapkan dirinya agar memiliki reputasi baik di masyarakat saat kelak saat 


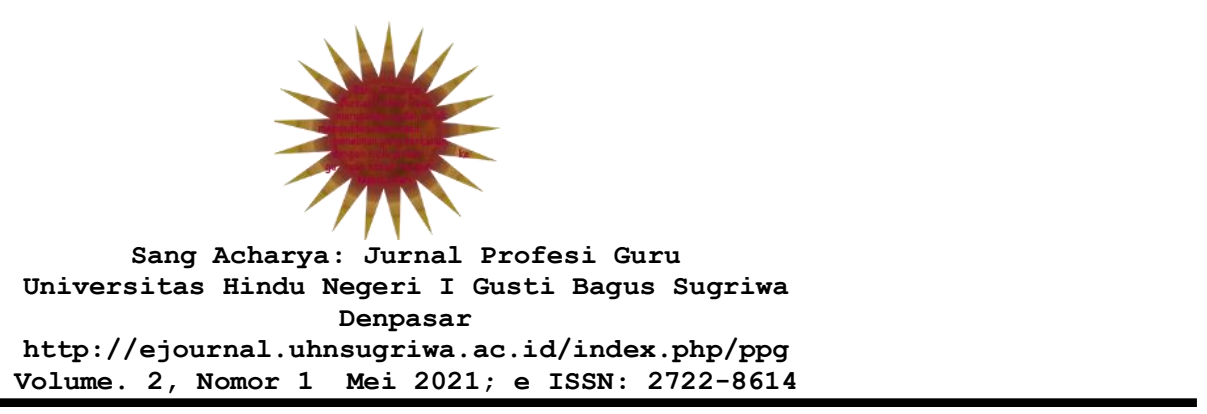

ia telah menikah. Reputasi yang baik di masyarakat adalah hal yang sangat susah untuk didapatkan, karena sekali dituduh bisa ngléak, selamanya tuduhan tersebut akan melekat pada seseorang (bahkan sampai ke keturunannya), sehingga dapat menyebabkan orang itu benar-benar belajar ngléak sebagai akibat dari rasa frustrasi, pelampiasan emosi, serta pembalasan dendam atas tuduhan tersebut.

Selain menyayangi diri sendiri, menyayangi orang tua juga merupakan sikap yang sangatlah wajib ditumbuhkan sejak dini. Sugesti tradisional Bali yang menyatakan bahwa tidak boleh memotong kuku pada malam hari memberikan pewarah pada anak bahwa apabila sang anak memang sayang dengan orang tuanya dan ingin melihat orang tuanya hidup lebih lama, maka ia tidak akan pernah memotong kukunya di malam hari. Tidak boleh memotong kuku pada malam hari sebenarnya tiada lain adalah untuk menjaga keselamatan sang anak,

karena saat malam hari penglihatan kurang jelas dan bisa beresiko sang anak memotong kuku hingga ke bagian kutikulanya. Hal tersebut bisa menimbulkan luka yang sangat menyakitkan. Untuk mencegah hal tersebut, maka sugesti tradisional menyatakan bahwa apabila memotong kuku pada malam hari, maka orang tua akan cepat meninggal agar sang anak merasa takut dan tidak berani memotong kukunya di malam hari. Secara tidak langsung, orang tua yang menanamkan sugesti tersebut kepada anaknya telah mengajarkan anak bahwa sang anak harus mengendalikan perilaku demi rasa cintanya kepada orang tua. Oleh karena itu, sang anak akan senantiasa menurut, karena tidak ingin kehilangan orang tuanya.

\section{PENUTUP}

Kearifan lokal Bali adalah aset kebudayaan berkualitas dengan nilai-nilai universal yang masih relevan hingga saat ini. Salah satu kearifan lokal tersebut adalah sugesti tradisional Bali yang memiliki peranan sebagai landasan pendidikan etika dan moralitas pada anak usia dasar. Sugesti tradisional Bali memiliki pola wacana sederhana yang terdiri dari dua poin penting, yaitu sebab dan akibat. Secara sederhana isi dari sugesti tradisional Bali adalah apabila seseorang melakukan sesuatu yang salah, maka akan menimbulkan akibat yang merugikan. Di Bali sangatlah banyak terdapat sugesti tradisional, namun terdapat beberapa yang familiar dan paling sering diucapkan oleh orang tua kepada anaknya, yaitu: "Sing dadi negakin galeng, nyanan busul jité" (tidak boleh menduduki bantal, nanti pantatnya bisul), "Sing dadi negakin lesung,nyanan jité amun lesungé gedénné" (tidak boleh menduduki tempat menumbuk padi, nanti pantatnya sebesar tempat menumbuk padi), "Sing dadi ngutang nasi, nyanan mati siap selemé" (tidak boleh membuang-buang nasi, nanti ayam hitamnya mati), "Sing dadi ngetep kuku peteng-peteng, nyanan énggal reramanémati" (tidak boleh potong kuku di malam hari, nanti orang tuanya bisa cepat meninggal), "Sing dadi negakin talenan, nyanan kebus jité" (tidak boleh menduduki talenan, karena dapat menyebabkan pantat menjadi panas), "Sing dadi nyampat peteng-peteng, nyanan ada anak nugtug" (tidak boleh menyapu di malam hari, nanti ada yang 


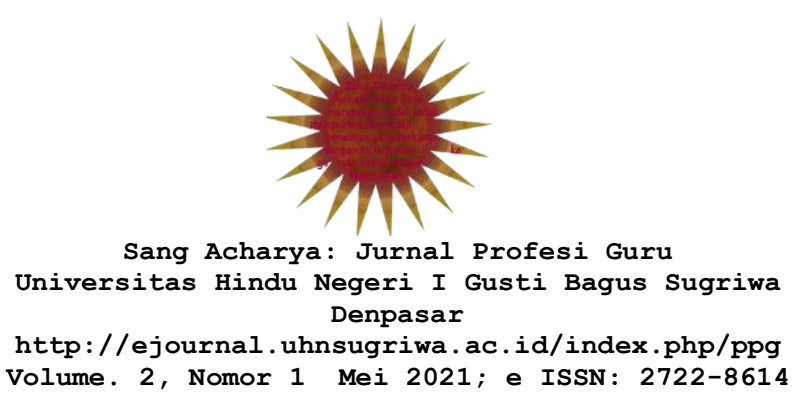

membuntuti), dan "Sing dadi mambuh nuju kajeng kliwon, nyanan kadena bisa ngleak" (tidak boleh keramas saat hari kajeng kliwon, nanti dikira memiliki ilmu hitam/magic/bisa ngléak). Keseluruhan sugesti tradisional tersebut memiliki peranan penting dalam membentuk etikadan moral anak, seperti: membentuk anak menjadi pribadi yang sopan, membentuk sikap tenggang rasa dan peduli sosial, menumbuhkan sikap menghargai anugerah Tuhan berupa makanan, dan menumbuhkan sikapmenyayangi diri sendiri dan orang lain.

Sugesti tradisional Bali merupakan sarana yang masih sangat relevan untuk membentuk etika serta moral anak menuju ke generasi yang memiliki karakter mulia. Oleh karena itu, para orang tua di Bali hendaknya senantiasa menanamkan sugesti tradisional pada anak agar senantiasa anak memiliki modal kuat dalam pembentukan karakternya. Penanaman tersebut dilakukan dengan penuh kasih sayang dan senantiasa dilakukan secara berulang-ulang agar sang anak senantiasa mengerti dan memahami secara utuh sugesti tradisional tersebut. Dengan pemahaman anak yang baik terhadap sugesti tradisional, maka akan terwujud perilaku yang positif dari sang anak. Tujuannya hanyalah satu, yaitu mempersiapkan generasi yang suputra untuk Indonesia Emas di masa mendatang. 


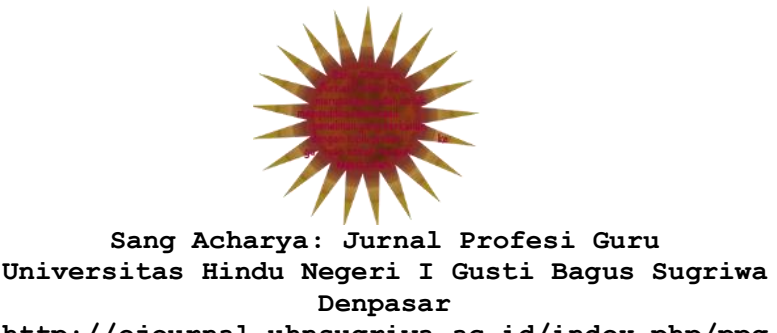

http: //ejournal .uhnsugriwa.ac.id/index.php/ppg

Volume. 2, Nomor 1 Mei 2021; e ISSN: 2722-8614

\section{DAFTAR PUSTAKA}

Alit. 2009. Pesan-Pesan Kebijaksanaan Bali Klasik (Dalam Dongeng, Lagu, Syair, dan Pertanda Alam). Denpasar: Pustaka Bali Post.

Asthararianty, dkk, 2016. Mengungkap Nilai-Nilai Simbolis di Balik warna Tradisional Bali Nawa Sanggha melalui Rancangan Desain Buku. Dalam "Nirmana", Volume 16 No. 1 Januari. Bandung: Institut Teknologi Bandung.

Danandjaja, James. 1997. Folklor Indonesia, Ilmu Gosip, Dongeng dan Lain-lain. Jakarta: Grafik Press.

Jawetz, E., J. Melnick dan E. Adelberg. 2008. Mikrobiologi Kedokteran Edisi 23. Jakarta: EGC.

Astono, Sigit. 2002. Lesung Banarata Karawitan di Akar Rumput. Dalam "Keteg" Jurnal Pengetahuan-Pemikiran \& Kajian tentang Bunyi, Volume 2 No. 1 Mei. Surakarta: STSI. 